\title{
Komite Sekolah dan Pengembangan Pendidikan: Studi Kasus SMA Makassar¹
}

\author{
Nurindah Sari², Kaharuddin ${ }^{3}$, Zainudin Hassan ${ }^{4}$
}

\begin{abstract}
Abstraksi
Tujuan dari penelitian ini adalah untuk mendeskripsikan bentuk kontribusi komite sekolah dalam pengembangan pendidikan dengan menggunakan studi kasus percontohan di SMA Makassar. Penelitian ini mendeskripsikan faktor penghambat peran komite sekolah dalam pengembangan pendidikan di SMA Makassar. Metode kualitatif deskriptif dengan pendekatan studi kasus yang digunakan dalam penelitian ini. Hasil penelitian menunjukkan bahwa bentuk kontribusi komite sekolah dalam pengembangan pendidikan hanya terlihat pada pemberian pertimbangan atau ide-ide formal, mengontrol dan mengawasi siswa, serta menjadi mediator antara pihak sekolah dengan orang tua siswa dan masyarakat. Salah satu faktor penting yang menghambat komite sekolah dalam pengembangan pendidikan lebih lanjut adalah persepsi umum bahwa komite sekolah tidak memiliki dana sehingga banyak anggota komite sekolah merasa tidak memiliki kewajiban dalam menyelesaikan persoalan infrastuktur dan perolehan sumberdaya untuk sekolah.
\end{abstract}

Kata kunci: komite sekolah, pengembangan pendidikan, peran mediator pendidikan, Sekolah Menengah Atas (SMA)

\begin{abstract}
The purpose of this study is to describe the contribution of the school council for educational development by exemplyfying the case study in the Makassar Highschool (SMA Makassar). This study describes the inhibiting factors of the school council's role for developing educational progress in the SMA Makassar. Descriptive qualitative method with a case study approach applied for this study. The study result shows that the school council contributions for educational development are only viewed for providing formal considerations or ideas, controlling and supervising students, as well as being a mediator for the school, the parents of students and the community. One important factor that hinders the school council for further educational development is a common perception that the school council does not have funds, therefore the school council members feel that there is no obligation to oversee problems of the school infrastructure and acquisition of resources.
\end{abstract}

Keywords: school council, educational development, educational mediator role, high school

\section{A. Pendahuluan}

Reformasi pemerintahan yang terjadi di Indonesia yang dimulai sejak tahun 1997 telah mengakibatkan terjadinya pergeseran penyelenggaraan pemerintahan yang kemudian melahirkan paradigma baru dari sentralisasi ke desentralisasi. Hal ini ditandai dengan pemberian otonomi yang luas dan nyata kepada daerah dalam waktu seketika. Fasli Jalal dan Dedi Supriadi (2001:

32) berpendapat pemberian otonomi ini dimaksudkan untuk menjadikan daerah lebih mandiri dan lebih memberdayakan masyarakat sehingga lebih leluasa dalam mengatur dan melaksanakan kewenangannya atas prakarsa sendiri. Pemberian otonomi yang luas dan bertanggung jawab dilaksanakan dengan berdasarkan prinsip-prinsip demokrasi, peran serta

\footnotetext{
${ }^{1}$ Untuk kutipan atau sitasi artikel ini: Sari, Nurindah, Kaharuddin, Hassan, Zainudin. 2020. “Komite Sekolah dan

Pengembangan Pendidikan: Studi Kasus SMA Makassar.” Jurnal Pemikiran Sosiologi Vol 7 (1): $82-92$

2 Program Studi Pendidikan Sosiologi, FKIP Universitas Muhammadiyah Makassar. Email: indahsarinur599@gmail.com

${ }^{3}$ Idem. Email: kaharuddin@unismuh.ac.id

${ }^{4}$ Universiti Teknologi Malaysia. Email: p-zainudin@utm.my
} 
Jurnal Pemikiran Sosiologi Volume 7 No.1 2020

Komite Sekolah dan Pengembangan Pendidikan: Studi Kasus SMA Makassar

Nurindah Sari, Kaharuddin, Zainuddin Bin Hassan

masyarakat, pemerataan, berkeadilan dan memperhatikan potensi serta keanekaragaman daerah dengan titik sentral otonomi pada tingkat wilayah yang paling dekat dengan rakyat, yaitu kabupaten dan kota. Hal yang dipandang lebih esensial dari otonomi daerah adalah semakin besarnya tanggung jawab daerah untuk mengurus tuntas segala permasalahan yang tercakup dalam pembangunan masyarakat di daerahnya, termasuk bidang pendidikan.

Perubahan paradigma sistem pemerintahan dari sentralisasi menjadi desentralisasi yang ditandai dengan adanya pemberian otonomi yang luas kepada daerah (UU Nomor 22 Tahun 1999 tentang Pemerintahan Daerah) telah membuka peluang bagi masyarakat untuk dapat meningkatkan peran sertanya dalam pengelolaan pendidikan. Peningkatan peran serta yang dimaksud adalah penciptaan lingkungan yang terbuka dan demokratik, dimana warga sekolah (guru, siswa, karyawan) dan masyarakat (orang tua siswa, tokoh masyarakat, ilmuwan, usahawan, dsb), didorong untuk terlibat secara langsung dalam penyelenggaraan pendidikan, mulai dari pengambilan keputusan, pelaksanaan, dan evaluasi pendidikan yang diharapkan dapat meningkatkan mutu pendidikan.

Wahjosumidjo (2002: 331) mengatakan keyakinan bahwa jika seseorang dilibatkan (berpartisipasi) dalam penyelenggaraan pendidikan, maka yang bersangkutan akan mempunyai rasa memiliki terhadap sekolah, sehingga yang bersangkutan juga akan bertanggung jawab dan berdedikasi sepenuhnya untuk mencapai tujuan sekolah tersebut. Singkatnya makin besar tingkat partisipasi, makin besar pula rasa memiliki; makin besar rasa memiliki, makin besar pula rasa tanggung jawab; dan makin besar rasa tanggung jawab, makin besar pula dedikasinya. Tentu saja pelibatan warga sekolah dalam penyelenggaraan sekolah ini harus mempertimbangkan keahlian, batas kewenangan, dan relevansinya dengan tujuan partisipasi. Peningkatan partisipasi warga sekolah dan masyarakat dalam penyelenggaraan sekolah akan mampu menciptakan keterbukaan, kerjasama yang kuat, akuntabilitas, dan demokrasi pendidikan.

Dalam rangka pelaksanaan otonomi pendidikan sebagai salah satu bagian dari otonomi daerah maka sebagai realisasi dari peran serta masyarakat dibidang pendidikan diperlukan suatu wadah yang dapat mengakomodasi pandangan, aspirasi dan menggali potensi masyarakat untuk menjamin terciptanya demokratisasi, transparansi dan akuntabilitas pendidikan. Menurut Djam'an Satori (2001), sebagai konsekuensi untuk mengakomodasi aspirasi, harapan dan kebutuhan stakeholder sekolah, maka perlu dikembangkan adanya wadah untuk menampung dan menyalurkannya. Wadah tersebut berfungsi sebagai forum dimana representasi para stakeholder Sekolah terwakili secara proporsional. Dalam berbagai dokumen yang ada dan consensus yang telah muncul dalam berbagai forum, wadah ini diberi nama "komite sekolah". Badan sejenis ini di Australia disebut sebagai school council (Chan \& Chui, 1997).

Dalam pengertian lain, Mulyono (2008: 258) menjelaskan bahwa komite sekolah merupakan suatu badan yang berfungsi sebagai forum resmi untuk mengakomodasikan dan membahas hal-hal 
Jurnal Pemikiran Sosiologi Volume 7 No.1 2020

Komite Sekolah dan Pengembangan Pendidikan: Studi Kasus SMA Makassar

Nurindah Sari, Kaharuddin, Zainuddin Bin Hassan

yang menyangkut kepentingan kelembagaan sekolah. Sedangkan menurut keputusan Menteri Pendidikan Nasional Nomor 044/U/2002, komite sekolah merupakan sebuah badan mandiri yang mewadahi peran serta masyarakat dalam rangka meningkatkan mutu, pemerataan, dan efisiensi pengelolaan pendidikan di satuan pendidikan. Hasbullah (2006: 90) menjelaskan bahwa untuk penamaan badan disesuaikan dengan kondisi dan kebutuhan daerah masing-masing satuan pendidikan, seperti komite sekolah, majelis madrasah, komite $\mathrm{TK}$, atau nama-nama lain yang disepakati bersama.

Keberadaan dewan pendidikan dan komite sekolah merupakan amanat rakyat yang telah tertuang dalam UU Nomor 25 Tahun 2000 tentang Progam Pembangunan Nasional (Propenas) tahun 2000-2004, dan sebagai implementasi dari UU tersebut telah diterbitkan Keputusan Menteri Pendidikan Nasional Nomor 044/U/2002 tanggal 2 April 2002 tentang Dewan Pendidikan dan Komite Sekolah.

Amanat rakyat ini selaras dengan kebijakan otonomi daerah, yang telah memosisikan Kabupaten/Kota sebagai pemegang kewenangan dan tanggung jawab dalam penyelenggaraan pendidikan. Mulyasa (2002: 11) menjelaskan bahwa pelaksanaan pendidikan di daerah tidak hanya diserahkan kepada Kabupaten/Kota, melainkan juga dalam beberapa hal telah diberikan kepada satuan pendidikan, baik pada jalur pendidikan sekolah maupun luar sekolah. Dengan kata lain, keberhasilan dalam penyelenggaraan pendidikan tidak hanya menjadi tanggung jawab pemerintah pusat, melainkan juga pemerintah provinsi,
Kabupaten/Kota, dan pihak sekolah, orangtua, dan masyarakat atau stakeholder pendidikan. Hal ini sesuai dengan konsep partisipasi berbasis masyarakat (community based participation) dan Manajemen Berbasis Sekolah/MBS (school based management) yang kini tidak hanya menjadi wacana, tetapi mulai dilaksanakan di Indonesia.

Fasli Jalal dan Dedi Supriadi (2001: 149) menjelaskan inti dari penerapan kedua konsep tersebut adalah bagaimana agar sekolah dan semua yang berkompeten atau stakeholder pendidikan dapat memberikan layanan pendidikan yang berkualitas. Untuk itu diperlukan kerjasama yang sinergis dari pihak sekolah, keluarga, dan masyarakat atau stakeholder lainnya secara sistematik sebagai wujud peran serta dalam melakukan pengelolaan pendidikan melalui dewan pendidikan dan komite sekolah.

Hal tersebut tertuang dalam UndangUndang No 20 Tahun 2003 tentang Sistem Pendidikan Nasional yang menyatakan bahwa: "Komite sekolah atau madrasah adalah lembaga mandiri yang beranggotakan orang tua atau wali peserta didik, komunitas sekolah, serta tokoh masyarakat yang peduli pendidikan. Komite sekolah atau madrasah, sebagai lembaga mandiri, dibentuk dan berperan dalam peningkatan mutu pelayanan dengan memberikan pertimbangan, arahan dan dukungan tenaga, sarana dan prasarana, serta pengawasan pendidikan pada tingkat satuan pendidikan". 
Jurnal Pemikiran Sosiologi Volume 7 No.1 2020

Komite Sekolah dan Pengembangan Pendidikan: Studi Kasus SMA Makassar

Nurindah Sari, Kaharuddin, Zainuddin Bin Hassan

\section{B. Metode Penelitian}

Penelitian tentang kontribusi komite sekolah dalam pengembangan pendidikan di SMA Makassar ini adalah penelitian berbasis studi kasus yang menggunakan pendekatan kualitatif deskriptif. Penelitian ini bertujuan untuk memahami situasi yang ada di lapangan atau lokasi penelitian sebagai percontohan praktik dilaksanakannya komite sekolah. Melalui penelitian ini dapat diartikan sebagai proses investigatif yang di dalamnya peneliti dapat melibatkan diri ke dalam upaya-upaya penting, seperti mengajukan pertanyaanpertanyaan, mengumpulkan data yang spesifik dari para partisipan, menganalisis data dan menafsirkan makna data yang telah didapatkan peneliti (Miles \& Huberman, 1984).

Adapun partisipan atau informan yang terlibat di dalam penelitian ini yaitu dari pihak sekolah dengan komite sekolah yang meliputi Kepala Sekolah, Wakil Kepala Sekolah bagian Humas, Guru, Siswa, dan Ketua Komite Sekolah di sekolah yang menjadi studi kasus dalam penelitian ini, yakni SMA Makassar.

SMA Makassar merupakan salah satu sekolah menengah atas yang ada di Kelurahan Tamallayang, Kecamatan Bontonompo, Kabupaten Gowa. SMA Makassar didirikan pada tanggal 08 Februari 1988. Pada tahun ajaran 1988/1999, sekolah ini dinyatakan berdiri berdasarkan SP Pembukaan: Tanggal 08-02-1998/Nomor, 052/0/1988. Sekolah ini merupakan salah satu sekolah favorit yang ada di Kabupaten Gowa dan sudah mendapatkan akreditasi A pada tanggal 23 November 2017.
Secara keseluruhan jumlah siswa di SMA Makassar pada tahun 2018-2019 kurang lebih sebanyak 939 siswa yang terdiri dari tiga tingkat, yaitu kelas X, XI, dan XII, dengan rincian jumlah siswa laki-laki sebanyak 396 siswa dan perempuan sebanyak 543 siswa yang menempati 30 ruang kelas. Peserta didik pada umumnya dari kecamatan Bontonompo dan daerah sekitarnya. Adapun jumlah seluruh personil sekolah sebanyak 72 yang terdiri atas guru PNS sebanyak 40 guru termasuk Kepala Sekolah, guru honorer sebanyak 18 guru, karyawan PNS sebanyak 4 orang termasuk Kepala TU, dan karyawan honorer sebanyak 10 orang.

SMA Makassar merupakan salah satu sekolah negeri yang menyikapi dengan serius permasalahan pendidikan terutama yang menyangkut pengembangan pendidikan untuk meningkatkan mutu/kualitas pendidikan di SMA Makassa. Dalam menyelesaikan permasalahan untuk pengembangan pendidikan, tentu dalam menyikapi permasalahan tersebut tidaklah bekerja sendiri, namun SMA Makassar mengikutsertakan stakeholder yang ada. Hal seperti ini yang tertuang dalam salah satu misi SMA Makassar yakni menerapkan Total Quality Managemen (TQM) dengan berupaya melibatkan seluruh warga sekolah dan kelompok kepetingan yang terkait dengan sekolah (stakeholder). Artinya, SMA Makassar dalam hal ini selalu memberikan ruang kepada setiap stakeholder yang ada untuk dapat terlibat dalam pengembangan pendidikan di SMA Makassar. Langkah ini tentu diambil karena pihak sekolah menyadari bahwa berfikir, berbuat, dan bekerja akan lebih baik jika dilakukan secara bersama-sama. 
Jurnal Pemikiran Sosiologi Volume 7 No.1 2020

Komite Sekolah dan Pengembangan Pendidikan: Studi Kasus SMA Makassar

Nurindah Sari, Kaharuddin, Zainuddin Bin Hassan

Pengembangan pendidikan hingga saat ini masih merupakan masalah bagi semua pihak terutama dalam rangka peningkatan kualitas pendidikan, maka pihak sekolah berusaha untuk dapat mengikutsertakan keterlibatan komite sekolah dalam pelaksanaan kegiatan belajar mengajar. Salah satu bentuk keterlibatan komite sekolah yakni pihak sekolah, dalam hal ini kepala sekolah dan para guru, disertai persetujuan komite sekolah menetapkan sasaran program, baik untuk jangka pendek, jangka menengah, dan jangka panjang. Sasaran program yang dimaksud untuk mewujudkan visi dan misi sekolah. Hal ini dimaksudkan, agar semua elemen masyarakat dapat ikut serta dalam menyukseskan pendidikan putraputrinya dengan kualitas yang lebih baik. Karena itu juga, hal ini dipandang sebagai bagian dari respon terhadap kebijakan-kebijakan pemerintah yang telah dituangkan dalam beberapa Undang-undang dan Keputusan Menteri Pendidikan Nasional yang terkait dengan pengikutsertaan masyarakat dalam rangka mewujudkan pendidikan yang berkualitas.

\section{Kerangka Konseptual Peran Komite Sekolah}

Hasbullah (2006: 90) menjelaskan bahwa peran komite sekolah yang berkedudukan di setiap satuan pendidikan merupakan badan mandiri yang tidak memiliki hubungan hierarkis dengan lembaga pemerintahan. Komite sekolah dapat terdiri dari satuan pendidikan atau beberapa satuan pendidikan yang berbeda jenjang, tetapi berada pada lokasi yang berdekatan, atau satuan-satuan pendidikan yang dikelola oleh suatu penyelenggara pendidikan, atau karena pertimbangan orang lain. Pada dasarnya posisi komite sekolah berada ditengah- tengah antara orang tua murid, murid, guru, kepala sekolah, masyarakat setempat, dan kalangan swasta di satu pihak dengan pihak sekolah sebagai institusi, dinas pendidikan wilayah dan pemerintah daerah di pihak lainnya. Dengan kata lain, peran komite sekolah diharapkan dapat menjembatani kepentingan kedua belah pihak.

Komite sekolah yang dibentuk untuk menunjang penyelenggaraan pendidikan di sekolah berperan meningkatkan kualitas pelayanan pendidikan. Komite itu dibentuk untuk mewadahi dan meningkatkan partisipasi para stakeholder sekolah untuk turut merumuskan, menetapkan, melaksanakan, dan memonitor pelaksanaan kebijakan sekolah dan pertanggungjawaban yang terfokus pada kualitas pelayanan terhadap peserta didik secara proporsional dan terbuka. Komite juga mewadahi partisipasi para stakeholder untuk turut serta dalam manajemen sekolah sesuai dengan peran dan fungsinya, berkenaan dengan perencanaan, pelaksanaan, dan evaluasi program sekolah secara proporsional dalam rangka mewujudkan visi "Masyarakat Sekolah" yang memiliki loyalitas terhadap peningkatan mutu sekolah.

Adapun peran komite sekolah berdasarkan Kepmendiknas Nomor 004/U/2002 adalah sebagai berikut:

(1). Pemberi pertimbangan (advisory agency) dalam penentuan dan pelaksanaan kebijakan pendidikan.

Komite sekolah sebagai badan pertimbangan bagi sekolah memiliki arti, bahwa komite sekolah dipandang sebagai mitra kerja kepala sekolah yang dapat diajak bermusyawarah 
Jurnal Pemikiran Sosiologi Volume 7 No.1 2020

Komite Sekolah dan Pengembangan Pendidikan: Studi Kasus SMA Makassar

Nurindah Sari, Kaharuddin, Zainuddin Bin Hassan

tentang masa depan sekolah. Melalui komite sekolah, orang tua dan masyarakat dapat ikut merumuskan visi, misi, tujuan, sasaran yang akan dicapai oleh sekolah, sampai dengan menetapkan cara atau strategi yang akan ditempuh untuk mencapainya yang berupa rumusan kebijakan, program, dan kegiatan sekolah.

\section{(2). Pendukung layanan pendidikan (supporting} agency), baik yang berwujud finansial, pemikiran, maupun tenaga dalam penyelenggaraan pendidikan di satuan pendidikan.

Peran komite sekolah sebagai pendukung bagi penyelenggaraan dan upaya peningkatan kualitas pendidikan dapat berupa dukungan finansial, tenaga, dan dukungan pikiran. Secara nyata pemberian dukungan ini dapat diwujudkan diantaranya dengan pemecahan masalah kekurangan guru, biaya sekolah bagi anak kurang mampu, dan tenaga untuk ikut memperbaiki sekolah yang rusak. Pemberdayaan bantuan sarana dan prasarana yang diperlukan di sekolah melalui sumber daya yang ada pada masyarakat, hal ini dilakukan dengan koordinasi dengan dewan pendidikan.

\section{(3) Pengontrol (controlling agency) dalam rangka} tranparansi dan akuntabelitas penyelenggaraan dan keluaran pendidikan disatuan pendidikan.

Peran pengawasan yang dijalankan oleh komite sekolah merupakan jenis pengawasan masyarakat. Fungsi pengawasan yang dilakukan meliputi kontrol terhadap pengambilan keputusan dan perencanaan pendidikan di sekolah, disamping alokasi dana dan sumber-sumber daya bagi pelaksanaan program di sekolah. Komite sekolah juga melakukan fungsi kontrolnya terhadap keberhasilan pendidikan di sekolah yang dilihat dari mutu output pendidikan. Hasil pengawasan terhadap sekolah akan dijadikan bahan pertimbangan yang cukup menentukan bagi penyelenggaraan pendidikan dan peningkatan kualitas/mutu pendidikan.

(4) Mediator antara pemerintah (eksekutif) dengan masyarakat di satuan pendidikan.

Komite sekolah sebagai penghubung atau mediator antara sekolah, orang tua, dan masyarakat memiliki arti, bahwa aspirasi orang tua dan masyarakat akan disalurkan melalui Komite Sekolah untuk disampaikan kepada sekolah. Selain itu, aspirasi orang tua dan masyarakat secara langsung dapat disalurkan oleh masyarakat kepada kepala sekolah. Peran sebagai mediator ini memerlukan kecermatan dalam mengidentifikasi kepentingan, kebutuhan, dan keluhan orang tua siswa dan masyarakat. Aspirasi yang disalurkan melalui komite sekolah dimanfaatkan oleh sekolah sebagai masukan bagi koreksi ke arah perbaikan. Komite sekolah juga berperan dalam mensosialisasikan berbagai kebijakan dan program yang telah ditetapkan sekolah sehingga dapat bersifat akuntabel (dapat dipertanggungjawabkan) kepada masyarakat. Bagi komite sekolah, peran yang harus dijalankan sebagai mediator adalah pemberdayaan sumber daya yang ada pada orang tua siswa bagi pelaksanaan pendidikan di sekolah.

Meski demikian, keberadaan komite sekolah terkadang terbentur beberapa keterbatasan (hambatan) dan hanya dijadikan sebagai formalitas untuk melengkapi persyaratan administrasi sekolah. Pihak sekolah terkadang justru merasa 
Jurnal Pemikiran Sosiologi Volume 7 No.1 2020

Komite Sekolah dan Pengembangan Pendidikan: Studi Kasus SMA Makassar

Nurindah Sari, Kaharuddin, Zainuddin Bin Hassan

terintimidasi dengan keberadaan komite sekolah.

Tugas komite sekolah akhirnya hanya terbatas pada posisi formalitas itu saja, meskipun juga dituntut untuk berperan secara luas dalam penyelenggaraan pendidikan di sekolah. Peran komite sekolah juga tidak dapat terlalu jauh mencampuri secara teknis manajerial sekolah karena hal tersebut merupakan wewenang kepala sekolah, meskipun di sisi lain tetap harus melakukan fungsi pengawasan.

Dalam kenyataannya, fenomena di dunia pendidikan juga menunjukkan bahwa masih banyak pengurus komite sekolah yang tidak mengetahui hal-hal yang menjadi tugas atau kewajiban yang harus dilakukannya. Komite sekolah hanya dijadikan sebagai simbol bagi pihak sekolah untuk mendapatkan bantuan dari pemerintah. Hal ini sesungguhnya merupakan suatu praktik dan cara pandangan yang menyimpang. Padahal fungsi komite sekolah seharusnya diharapkan mampu memberikan saran serta mendukung programprogram yang diajukan oleh sekolah. Selain itu komite sekolah harus dapat menjadi mitra (partner) sekolah serta mediator untuk dapat mencari dukungan dari masyarakat dalam mengembangkan potensi yang ada di sekolah. Hal tersebut secara ideal diharapkan dapat meningkatkan pengembangan sekolah.

\section{Temuan dan Analisis: Faktor Pendukung dan Hambatan Kontribusi Komite Sekolah}

Dari pengamatan penelitian berdasarkan studi kasus di SMA Makassar, maka beberapa temuan tematik berikut ini menjelaskan tentang peranan komite sekolah. Pertama, kontribusi komite sekolah sebagai pemberi pertimbangan (advisory agency) dalam penentuan dan pelaksanaan kebijakan pendidikan di satuan pendidikan. Peran komite sekolah sebagai badan pemberi pertimbangan (advisory agency) telah terlaksana dalam beberapa hal, misalnya ini dapat dilihat dari partisipasi komite sekolah dalam rapat-rapat penyusunan Rencana Kerja Sekolah (RKS), penyusunan kebijakan dan program-program sekolah dalam hal pengembangan sekolah, dan rutinitas dalam memberikan arahan kepada siswa dan terlebih jika ada siswa yang melanggar aturan sekolah dan atau ada kebijakan baru yang dibuat oleh sekolah, maka anggota komite sekolah akan mengkomunikasikan hal tersebut dengan orang tua siswa.

Meskipun telah menjalankan fungsi sebagai mediator pendidikan, keberadaan komite sekolah kurang terlibat dalam hal memberikan pertimbangan terhadap penyediaan dan penggunaan sarana dan prasarana yang dibutuhkan oleh sekolah, memberi pertimbangan terhadap penggunaan dan pemanfaatan anggaran atau dana yang diperoleh sekolah, memberi masukan tentang rancangan anggaran pendapatan dan belanja sekolah (RAPBS), dan dalam hal menyelenggarakan rapat rancangan aggaran pendapatan dan belanja sekolah (RAPBS). Hal-hal yang berkaitan dengan pertimbangan rancangan anggaran atau dana, justru 
Jurnal Pemikiran Sosiologi Volume 7 No.1 2020

Komite Sekolah dan Pengembangan Pendidikan: Studi Kasus SMA Makassar

Nurindah Sari, Kaharuddin, Zainuddin Bin Hassan

komite sekolah tidak banyak terlibat dalam hal itu.

Hal ini terjadi karena komite sekolah enggan memberikan pertimbangannya mengenai rancangan anggaran karena komite merasa tidak lagi memberi bantuan dana kepada pihak sekolah sehingga berdampak pada kurangnya partisipasi para anggota komite sekolah dalam hal memberikan pertimbangan-pertimbangan mengenai anggaran dana sekolah. Terlebih karena dana dari sekolah sepenuhnya berasal dari dana bantuan operasional sekolah (BOS) atau dari pemerintah yang dianggap sudah ada pengelolaanya tersendiri.

Kedua, kontribusi komite sekolah sebagai agen pendukung (supporting agency), baik yang berwujud finansial, pemikiran, maupun tenaga dalam penyelenggaraan pendidikan. Peran komite sekolah sebagai agen pendukung (supporting agency) hanya terlihat pada pemberian sumbangsih pemikiran saja atau memberikan saran dan ide-ide. Sementara dalam program kerja sekolah dibuat, disusun dan ditetapkan oleh pihak sekolah bersama dengan komite sekolah.

Di dalam menyusun program kerja sekolah tersebut harus disesuaikan dengan anggaran sekolah, yang mana anggaran dana sekolah di SMA Makassar sepenuhnya berasal dari Pemerintah atau dana bantuan operasional sekolah (BOS). Padahal ada harapan dari pihak sekolah bahwa komite sekolah dapat memberikan sumbangsih lebih dari itu. Tetapi karena terbentur keadaan atau kenyataan dengan pemahaman masyarakat yang menganggap bahwa pendidikan seharusnya gratis. Pemikiran ini muncul karena adanya peraturan daerah (Kabupaten) yang memiliki program pendidikan gratis. Sedangkan peraturan pendidikan gratis itu muncul pada saat satuan sekolah tingkat SMA masih di bawah naungan daerah (Kabupaten). Sedangkan sekarang kenyataannya, satuan pendidikan SMA itu ditangani oleh pemerintah Provinsi. Itu artinya pihak komite sekolah sudah bisa memberikan sumbangsih lebih berupa dukungan finansial kepada sekolah dalam rangka pengembangan pendidikan di SMA Makassar untuk meningkatkan kualitas atau mutu sekolah.

Ketiga, kontribusi komite sekolah sebagai agen pengontrol (controlling agency) dalam rangka transparansi dan akuntabilitas penyelenggaraan dan luaran (output) pendidikan. Peran komite sekolah dalam pengembangan pendidikan di SMA Makassar sebagai badan pengontrol atau pengawasan diwujudkan dengan terjun langsung ke lapangan yang dalam hal ini para anggota komite sekolah secara rutin datang ke sekolah, sehingga komite sekolah dapat mengetahui sejauh mana proses pelaksanaan program sekolah, apakah sesuai dengan kenyataan di lapangan, memeriksa atau mempelajari laporan-laporan pertanggungjawaban program sekolah tersebut untuk melakukan evaluasi terhadap program sekolah yang sudah dijalankan. Kontrol atau pengawasan yang dilakukan oleh komite sekolah pun tidak hanya pada siswa tetapi juga terlihat pada guru. Komite sekolah ikut memantau permasalahan yang dihadapi oleh siswa, ikut serta dalam menidaklanjuti siswa yang bermasalah, dan ikut serta dalam pengawasan guru yang sering kali tidak tepat waktu masuk mengajar pada saat pergantian jam pelajaran. Kontrol komite sekolah dalam pengawasan anggaran tidak terlalu intens karena adanya stigma bahwa komite sekolah tidak memiliki kontrol atas penggunaan anggaran 
Jurnal Pemikiran Sosiologi Volume 7 No.1 2020

Komite Sekolah dan Pengembangan Pendidikan: Studi Kasus SMA Makassar

Nurindah Sari, Kaharuddin, Zainuddin Bin Hassan

sekolah, terutama karena adanya anggapan bahwa dana operasional dari pemerintah seperti dana bantuan operasional sekolah (BOS) ini sudah ada yang mengatur, sehingga pihak komite sekolah hanya akan lebih banyak mengawasi programprogram sekolah saja.

Keempat, kontribusi komite sekolah sebagai mediator antara pemerintah (eksekutif) dan Dewan Perwakilan Rakyat Daerah (legislatif) dengan masyarakat. Kerjasama antara pihak sekolah dengan orang tua siswa ini sangat mutlak dilakukan. Pasalnya sebagaimana gambaran yang telah dipaparkan di atas, bahwa komite sekolah adalah wadah untuk menampung serta menganalisis aspirasi, ide-ide, tuntutan dan berbagai kebutuhan pendidikan yang diajukah oleh masyarakat ekstrnal (orang tua siswa dan masyarakat) ke masyarakat internal (pihak sekolah). Yang diharapkan dapat dijadikan masukan atau pertimbangan untuk sekolah dalam pengembangan pendidikan di SMA Makassar. Tidak hanya itu, komite sekolah juga berperan dalam mensosialisasikan berbagai kebijakan dan program yang telah ditetepakan sekolah sehingga dapat akuntabel (dipertanggung jawabkan) kepada masyarakat. Komite sekolah juga aktif dalam menyikapi berbagai permasalahan siswa yang kemudian akan dikomunikasikan kepada orang tua siswa.

Sementara itu, faktor yang menghambat peran komite sekolah dalam pengembangan pendidikan lebih lanjut di SMA Makassar terletak pada koordinasi yang melibatkan partisipasi masyarakat. Pelaksanaan program-program sekolah harusnya didukung oleh partisipasi masyarakat dan orang tua yang merupakan stakeholder yang penting. Masyarakat dan orang tua harus menjalin kerjasama dengan sekolah dalam upaya peningkatan kualitas pendidikan. Kenyataanya di lapangan partisipasi masyarakat dalam upaya peningkatan kualitas pendidikan daerah maupun nasional relatif masih sangat rendah sekali. Karena masih banyak masyarakat yang beranggapan bahwa permasalahan yang menyangkut sistem pendidikan adalah urusan mereka yang duduk di kursi pemerintahan, sehingga masyarakat umum yang menganggap diri sebagai rakyat kecilpun hanya bisa berpangku tangan seakan tidak berdaya, padahal mereka sendirilah yang akan menentukan kelangsungan masa depan mereka dan generasi mereka selanjutnya.

Di lain pihak, partisipasi orang tua masih terbatas pada pemberian bantuan finansial untuk mendukung operasional sekolah. Peran orang tua siswa belum dilibatkan secara langsung untuk duduk bersama-sama merencanakan, mengembangakan dan melaksanakan programprogram sekolah (pendidikan), sehingga partisipasi keterlibatan para stakeholder masih sangat rendah. Oleh karena itu, keberadaan komite sekolah seharusnya difungsikan seoptimal mungkin untuk diberdayakan sesuai dengan SK Mendiknas Nomor 044/U/2002 dan dalam operasionalnya komite sekolah harus berlandaskan pada partisipasi masyarakat dalam usaha meningkatkan kualitas pendidikan.

Hambatan komite sekolah sebagai badan pendukung dan pengawasan itu terkendala oleh peraturan pemerintah untuk tidak memungut biaya apapun di sekolah (program pendidikan gratis) ketika SMA masih dibawah naungan Pemerintah 
Jurnal Pemikiran Sosiologi Volume 7 No.1 2020

Komite Sekolah dan Pengembangan Pendidikan: Studi Kasus SMA Makassar

Nurindah Sari, Kaharuddin, Zainuddin Bin Hassan

daerah (Kabupaten). Padahal kenyataannya sekarang SMA Makassar sudah berada dalam naungan Pemerintah Provinsi Sulawesi Selatan, sehingga seharusnya komite sekolah bersama dengan pihak sekolah dapat mensosialisasikan hal ini agar nantinya orang tua siswa dan masyarakat tidak kaget ketika komite sekolah meminta iuran (sumbangan) dari mereka. Karena besar harapan pihak sekolah agar komite sekolah dapat memberikan dukungan materi atau penyediaan sarana dan prasarana di sekolah untuk pengembangan pendidikan di SMA Makassar demi tercapainya visi, misi, dan tujuan sekolah yang berdampak pada peningkatan kualitas atau mutu pendidikan di SMA Makassar.

\section{E. Kesimpulan}

Berdasarkan hasil penelitian yang telah dilakukan tentang kontribusi komite sekolah dalam pengembangan pendidikan di SMA Makassar, maka dapat disimpulkan bahwa kontribusi komite sekolah banyak diwujudkan dalam hal pemberian masukan atau ide-ide mengenai program sekolah dan kebijakan-kebijakan yang akan ditetapkan oleh pihak sekolah, melakukan pengawasan terhadap program sekolah, guru dan siswa agar berjalan sesuai dengan apa yang telah disepakati bersama, serta menjadi penghubung (mediator) antara pihak sekolah dengan orang tua siswa dan masyarakat dalam mensosialisasikan berbagai kebijakan dan program sekolah yang sebelumnya sudah disepakati bersama. Sedangkan kontribusi komite sekolah dalam hal pemberian bantuan dana secara finansial atau materi itu masih belum ada.
Faktor yang menghambat peran komite sekolah dalam pengembangan pendidikan lebih lanjut juga ditemui adanya fakta atau kenytaaan ketidakaktifan anggota-anggota komite sekolah karena kesibukan mereka dalam menjalani aktifitasnya masing-masing dan tidak adanya dukungan dana yang dapat diberikan oleh komite sekolah sehingga membuat anggota komite sekolah jarang melakukan pertemuan dengan orang tua siswa dan pihak sekolah. Adapun kegiatan di sekolah yang melibatkan komite sekolah seringkali hanya diwakili oleh ketua komite sekolah. Hal semacam itu terjadi karena kurangnya pengetahuan anggota komite sekolah mengenai peran dan fungsi komite sekolah serta kurangnya partisipasi dari orang tua siswa dan masyarakat dalam mendukung kinerja komite sekolah karena pemahaman yang berlaku secara umum bahwa pendidikan seharusnya bersifat gratis sehingga orang tua siswa dan masyarakat tidak lagi harus memberikan sumbangan yang berupa materi atau finansial untuk mendukung pengembangan pendidikan di SMA Makassar.

\section{Daftar Pustaka}

Amtu, Onisimus. 2013. Manajemen Pendidikan di Era Otonomi Daerah (Konsep, Strategi, dan Implementasi). Bandung: Alfabeta.

Arikunto, Suharsimi. 2013. Prosedur Penelitian: Suatu Pendekatan Praktik. Jakarta: Rineka Cipta.

Chan, Benjamin \& Chui, Hong Seung. "Parental Participation in School Councils in Victoria, Australia." International Journal of Education Management Vol 11 (3): 102-110. 
Jurnal Pemikiran Sosiologi Volume 7 No.1 2020

Komite Sekolah dan Pengembangan Pendidikan: Studi Kasus SMA Makassar

Nurindah Sari, Kaharuddin, Zainuddin Bin Hassan

Creswell, J.W. 2016. Research Design Pendekatan Metode Kualitatif, Kuantitatif, dan Campuran (Terj). Yogyakarta: Pustaka Pelajar.

Damsar. 2015. Pengantar Sosiologi Pendidikan. Jakarta: Prenadamedia Group.

Hasan, Hasmiana. 2014. "Fungsi Komite Sekolah Dalam Perkembangan dan Implementasi Program Sekolah di SD NEGERI 19 Kota Banda Aceh." Jurnal Pesona Dasar. 2 (3): 112.

Hasbullah. 2006. Otonomi Pendidikan: Kebijakan Otonomi Daerah dan Implikasinya terhadap Penyelenggaraan Pendidikan. Jakarta: Raja Grafindo.

Horton, Paul B., dan Hunt, Chester L. 1991. Metode Penelitian (Terj). Jakarta: Erlangga.

Jalal, Fasli dan Supriadi, Dedi. 2001. Reformasi Pendidikan Dalam Konteks Otonomi Daerah. Yogyakarta: Adicita Karya Nusa.

Kaharuddin. 2017. "Hubungan antara Kepemimimpinan Manajerial Kepala Sekolah dengan Kinerja Guru SMA Negeri Kabupaten Bulukumba." Jurnal Noken: IlmuIlmu Sosial Universitas Muhammadiyah Sorong Vol 2 (2): 29-42.

Keputusan Menteri Pendidikan Nasional No. 044/U/2002 Tanggal 2 April 2002 tentang Dewan Pendidikan dan Komite Sekolah.

Miles M. B., \& Huberman A. M. 1984. “Drawing Valid Meaning from Qualitative Data: Toward a Shared Craft." Educational Researcher, 13(5):20-30. DOI https://doi.org/10.3102/0013189X013005 020
Mulyasa, E. 2002. Kurikulum Berbasis Kompetensi: Konsep, Karakteristik dan Implementasi. Bandung: PT Remaja Rosdakarya.

Mulyono. 2008. Manajemen Administrasi dan Organisasi Pendidikan. Yogyakarta: Ar Ruzz Media.

Satori, Djam'an. 2001. Kurikulum dan Pembelajaran dalam rangka Otonomi Daerah. Bandung: CV Andira

UU Nomor 22 Tahun 1999 tentang Pemerintahan Daerah

UU Nomor 25 Tahun 2000 tentang Program Pembangunan Nasional (Propenas) tahun 2000-2004

UU No 20 Tahun 2003 tentang Sistem Pendidikan Nasional

Wahjosumijo. 2002. Kepemimpinan Kepala Sekolah, Tinjauan Teoritik dan Permasalahannya. Jakarta: Raja Grafindo Persada. 